The Supreme Court Law Review: Osgoode's Annual Constitutional Cases Conference

\title{
Judges and Politics: An Essay From Canada
}

Allan C. Hutchinson

Osgoode Hall Law School of York University, ahutchinson@osgoode.yorku.ca

Follow this and additional works at: https://digitalcommons.osgoode.yorku.ca/sclr

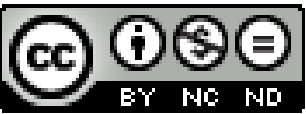

This work is licensed under a Creative Commons Attribution-Noncommercial-No Derivative Works 4.0 License.

\section{Citation Information}

Hutchinson, Allan C.. "Judges and Politics: An Essay From Canada." The Supreme Court Law Review: Osgoode's Annual Constitutional Cases Conference 25. (2004).

https://digitalcommons.osgoode.yorku.ca/sclr/vol25/iss $1 / 9$ 


\title{
Judges and Politics: An Essay From Canada
}

\begin{abstract}
Allan C. Hutchinson*
"We are here as on a darkling plain/ Swept with confused alarms of struggle and flight, / Where ignorant armies clash by night."
\end{abstract}

Matthew Arnold ${ }^{1}$

It is said of statistics that what they reveal is interesting, but what they hide is crucial. Much the same can be said of the present British debate over constitutional change and the courts. The various constitutional reforms proposed seem to be obvious and long overdue - abolishing the post of Lord Chancellor; setting up a Supreme Court separate from the House of Lords; and establishing a judicial appointments committee. However, at least as presented and dealt with by the government and the judges, while these innovations are interesting and generally positive, what they fail to mention or address is much more crucial and revealing. The government papers and the judiciary's response resolutely refuse to tackle the central issue of what it is that judges do and whether it is done in a suitably legitimate and proper way. For all the sound and fury of constitutional engagement, the main antagonists share a deep and disturbing assumption that judicial power has and will continue to be exercised in a non-political, objective and neutral manner. In this essay, by reference to the Canadian experience, I will challenge that assumption: it is not that judges are unprofessional or corrupt, but that adjudication is inescapably political and non-objective.

\footnotetext{
* The following essay is drawn from a special volume of LEGAL STUDIES devoted to 'The Reform of The House of Lords', but it is more about the Supreme Court of Canada than anything else. Professor, Osgoode Hall Law School, York University, Toronto. I am grateful to Derek Morgan, Luke Woolford, Michael Abdelkerim for their critical comments and helpful suggestions.

M. Arnold, "Dover Beach" in Dover Beach and Other Poems (New York: Dover Publications: 1994).
} 
Instead, I will offer a very different account of the adjudicative performance and propose a more complementary set of institutional reforms.

I.

What should a Supreme Court do to ensure that the government is meeting its constitutional responsibilities? Are there limits beyond which judges should not go in supervising government activities? If so, how are those limits to be determined? These important issues were confronted by the Canadian courts in the Fall of 2003 in Doucet. ${ }^{2}$ While the Canadian courts had over 20 years of experience under their collective belt in tackling the Charter of Rights and Freedoms, ${ }^{3}$ they had not staked out any comprehensive position on the precise role of courts in remedying Charter wrongs. Doucet obliged them to reveal their hand a little more fully. A trial judge had decided that it was incumbent on the Nova Scotia government to provide French-language secondary schooling in certain areas. While the government did not deny the parents' rights under section 23 of the Charter to have such schooling for their children, it had decided not to prioritize those rights and had delayed fulfilling its obligations. However, not only did the trial judge order the province to use its "best efforts" to provide school facilities and programs by specified dates, he also retained jurisdiction to hear reports on the status of those efforts. The province contended that this continuing judicial supervision inappropriately trespassed on the government's political discretion. The Nova Scotia Court of Appeal agreed and held that, while courts have broad ranging powers under section 24(1) of the Charter to fashion remedies, the Charter does not extend a court's jurisdiction to meddle in the details of a province's administrative management: there were limits to the courts' authority to interfere with what were matters of political judgment. A majority of the Supreme Court of Canada had no such qualms.

By the narrowest of 5-4 margins, the Supreme Court decided that the Constitution and legal tradition demanded that the trial judge should

\footnotetext{
2 Doucet-Boudreau v. Nova Scotia (Minister of Education), [2003] 3 S.C.R. 3, [2003] S.C.J. No. 63.

The Canadian Charter of Rights and Freedoms being Part I of the Constitution Act, 1982, being Schedule B of the Canada Act 1982 (U.K.), 1982, c. 11 [hereinafter "the Charter"].
} 
remain seized of the issue. Speaking for their colleagues, Iacobucci and Arbour JJ. recognized that the courts should be cautious in involving themselves in such matters. However, the courts must complement their purposive interpretation of Charter rights with a purposive approach to remedies in order to ensure that Charter rights are given full and meaningful protection. While the court must also be sensitive to the limits of its role as judicial arbiter and not interfere unduly with the roles of the other branches of governance, the judicial crafting of remedies will vary according to the right at issue and the context of each case: the advancement of democratic ends should not be accomplished by undemocratic means. Although the remedy was admittedly creative and novel, it did balance the parents' rights against the province's privilege to decide upon the details of educational planning. Accordingly, the majority held that, in the particular circumstances of the Nova Scotia schools and mindful that delay might defeat the parents' rights, a supervisory remedy "took into account, and did not depart unduly or unnecessarily from, the role of the courts in our constitutional democracy."4

The dissenters took a much more restrained line and were strongly critical of the majority's position. Drawing heavily on the common law doctrine of functus officio, the minority were not at all convinced that the trial judge's order was clear and maintained that, once a court had issued its decision, it ought to rely upon the government to act with reasonable diligence and in good faith: it was not the role of courts to act as direct overseers or superintendents of the executive function. Moreover, on behalf of the minority, LeBel and Deschamps JJ. insisted that it was vitally important that the courts respect the appropriate constitutional boundaries and balance between the different branches of government power: democracy demanded that the judicial role be limited and modest. Although it was imperative that citizens' Charter rights be properly and fully enforced, the minority took the definite view that this did not permit the courts to interfere in the legitimate exercise of executive discretion. Indeed, chastizing the majority for its rather cavalier approach to such delicate constitutional considerations, the minority considered that invasive remedies, such as the trial judge's in this case, were illegitimate and amounted to a virtual micro-management of ad-

4 Supra, note 2, at 28, per Iacobucci and Arbour JJ., as joined by McLachlin C.J., Gonthier, and Bastarache JJ. 
ministrative management which "led to the improper politicization of the relationship between the judiciary and the executive."5

Not surprisingly, the Supreme Court's decision was greeted with a deluge of public and academic commentary. "Activism" was the word on most people's lips. It sounds as if it is something positive - healthy, vital and purposeful. But, when used in connection with courts, many hear it only as having disturbing negative resonances - uppity, illegitimate and uncontrolled. At the heart of these responses was the concern that the courts might have gone beyond the bounds of what it is that unelected judges should be doing in a constitutional democracy; they might have vacated the realm of legal decision-making and trespassed into the arena of political discretion. The advent of the Charter of Rights and Freedoms in 1982 pushed the courts more into the spotlight and asked them to resolve more controversial disputes. With a higher public profile, the courts' work has come under closer and more critical scrutiny. Indeed, as the public and academic commentators tend to be the same people, the only difference between the public and academic debate is one of greater length and occasional subtlety of contribution. After over 20 years of debate about the legitimacy and reach of Charter review by courts over government action, the main thrusts of the response were predictable and well-rehearsed.

On one side were those who viewed the majority decision as further evidence that the judges had overstepped the bounds of their authority and competence: it was blatant and unwelcome "judicial activism." By interfering in the fiscal administration of public programmes, an unelected, unrepresentative, and unchecked judiciary had violated the separation of powers and imperilled "established traditions of responsible government." Some went so far as to see the decision as a "gratuitous and arrogant" power-grab which bordered on the "monarchical." However, on the other side, there was applause for a bold Court which had overcome the pusillanimity of some of its members to provide meaningful and effective protection to people's constitutional rights. If the Rule of Law was to be truly respected, it was thought essential that constitutional entitlements be effective remedies; it was not only desirable, but necessary that governments not be allowed to evade, complicate, or ignore court orders. Far from imperiling responsible government,

5 Id., at 45, per LeBel and Deschamps JJ., as joined by Major and Binnie JJ. 
the Doucet decision had contributed to the legitimacy of Canada's democratic commitments by giving the Charter "muscles" and "teeth.", While both sides have something important to contribute, I am not convinced that either has taken a defensible or convincing stance: the Charter debate is much broader and deeper than both sides contemplate or accept. Consequently, it is important to examine the courts' and the commentators' arguments at greater length and to explore an alternative viewpoint which contends that, whether activist or restrained, the judges are involved in an inevitably and thoroughly political endeavour: all efforts to separate law from politics are doomed to failure. Nevertheless, while my critique is decidedly radical, it is not deliberately negative. An acceptance that adjudication is throughly political does not strike the death-knell for democracy.

II.

The more traditional position is that taken by the minority and championed by a cadre of conservative academic critics. Accelerated by Charter adjudication, but not restricted to it, the Canadian judicial system is considered to have lost its way and to be hastily on its way to political hell in an activist handcart. The courts, especially the Supreme Court of Canada, are condemned as having become highly politicized and highly interventionist in their decisions and judgments. Effectively abandoning established legal principles and modes of legal reasoning, the judiciary has unwisely and indulgently shifted its focus to an analysis based on "values." Moreover, unlike the traditional understanding of judicial decision-making, this resort to values has more to do with a judge's own subjective political commitments than an objective assessment of a case's legal merits. Critics charge that, when recent judicial pronouncements are looked at as a body of work, they have not only become blatantly political, but reflect and instantiate a particular and partisan set of liberal-feminist commitments. In effect, these critics

6 For a sampling of the responses, see Gunter, "Judicial Arrogance Borders on Monarchial," National Post (20 November 2003) A18; Makin, "Top Court Pursuing Activism," The Globe and Mail (13 November 2003) A16; "Judicial Rule — Editorial," National Post (8 November 2003) A19; Young, "Court Gives Our Toothless Charter Sharp Fangs," The Toronto Star (23 November 2003) F07; and Roach, "Do We Want Judges with More Muscle?," The Globe and Mail (13 November 2003) A27. 
charge that "judicial activism" is not a careless aberration by an overworked judiciary, but a concerted dereliction of official duty by a politically-motivated judiciary. As such, there is an indignant call to return to the passive and neutral virtues of judicial restraint so that the promise of Canadian democracy can be redeemed. Of course, judicial activism has no part to play in such a restorative vision of law. ${ }^{7}$

While this nostalgic call for "judicial restraint" is expressed in the most passionate and least restrained terms, it has garnered considerable support. However, while this traditional critique is long on the details of the judiciary's current political fall from constitutional grace, its adherents are very light on how a purely legal mode of principled adjudication can be performed. While these exhortations to "stick to the law" are seductive, they offer little suggestion of how such a seemingly prosaic practice can be achieved. At a theoretical level, three initial observations come to mind. First, the ascertainment of legal principles is itself fraught with political contamination and content. "Established" is simply a way of saying that certain controversial moral or political commitments are now accepted by the legal community as settled; this is less an endorsement of the principles' apolitical nature and more an acknowledgment that general acceptance is a form of political validation. Second, the range of established principles is extremely broad and often encompasses competing maxims; there is no neutral or nonpolitical way to select between contradictory principles. Third, even if it is possible to isolate a relevant and exclusive legal principle, it is far from obvious how that general principle can be applied to particular facts in an entirely objective or impartial manner. ${ }^{8}$ In short, despite the critic's yearning for a simpler and more professional age, there is no purely technical and non-political way to engage in a principled mode of adjudication. This is especially true of the Charter. Not only is what amounts to "freedom" or "equality" the stuff of fierce ideological debate (and how one relates to the other), but how such values are to be enforced within section 1's "such reasonable limits as can be demonstrably

7 See, e.g., F. Morton and R. Knopff, The Charter Revolution and the Court Party (Peterborough: Broadview Press, 2000), and R. Martin, The Most Dangerous Branch: How the Supreme Court of Canada Has Undermined Our Law and Our Democracy (Montreal: McGill University Press, 2003).

${ }_{8}$ See A. Hutchison, Work-in-progress: Evolution and the Common Law (forthcoming, 2004). 
justified in a free and democratic society" merely invites judges to wade even deeper into the political waters. Adjudication necessarily involves political choice.

The fact is that the dissatisfaction with "judicial activism" is itself a political campaign. Behind the traditional rhetoric of principled adjudication, there is a very definite and partial political agenda. While it is understandable why such critics would prefer to occupy the neutral territory of formal constitutional technique rather than the contested turf of substantive political alignment, the effort to portray and promote a non-political mode of constitutional adjudication as being possible and desirable is a neat, but deceptive manoeuvre. When a closer look is taken at those occasions on which the critics raise the spectre of activism and those on which they do not, it will be seen that the difference is a blunt ideological one. Those decisions that do not fit their political agenda are condemned as activist and those that do fit are defended as appropriate. The constitutional line is one of their own political making. In general, those decisions which promote greater equality (for example, gay rights, aboriginal land claims, etc.) are dismissed as activist and illegitimate, whereas those which defend greater liberty (for example, election spending, male property rights, etc.) are showcased as valid exercises of judicial authority. Yet, in terms of their fit with the opaque constitutional text and the courts' activist tendencies, there is nothing to choose between them. It is only that some substantive values are preferred over others. Accordingly, the claim of "activism" is simply a veiled criticism that the courts are being too progressive and making decisions that do not reflect desirable conservative values: any court that stands by and lets constitutional values be ignored or belittled is at fault. But there is no technical or purely legal way to decide what those values are - law is politics by other means. The Charter is a contested site for political debate, not a definitive or neutral contribution to that debate.

Indeed, the Doucet decision itself is a good example of the disingenuity of those who reject "judicial activism" in the name of traditional judicial virtues. As the judgments of the minority reveal, theirs is less a rejection of political decision-making and more a championing of a particular and partial view of constitutional politics. Despite repeated incantations about "the separation of powers" and that "the legislature and the executive are ...the principal loci of democratic will," the minority makes no real effort to demonstrate that this is somehow an accepted legal principle as opposed to a contested political commitment. It is not 
at all that the majority rejects these general principles, it is that it has a different view of what those commitments demand in the particular circumstances. Moreover, it is unconvincing for the minority to maintain that the judiciary "should avoid turning themselves into managers of the public service." The entire history of administrative law confounds such trite observations about the need to "avoid interfering in the management of public administration." Furthermore, while it is important to recognize that there are constitutional boundaries to judicial action, those boundaries are not independently given, but are developed and negotiated by the courts themselves. While judges must respect that the executive and legislative branches are "the principal loci of democratic will,", that is not the point. In light of the fact that the judges, including members of the Doucet minority, regularly and rightly interfere with executive and legislative authority when they breach the Charter, the real point is when and how they should so interfere as a matter of constitutional requirement, not whether they ever should. Accordingly, the difference between the majority and minority judgments is not between legitimate and illegitimate modes of adjudication, but between competing visions of an appropriate constitutional and democratic order. Each has to be defended in political terms: there is simply no method by which to declare that one is more intrinsically legal and, therefore, noncontestable than another. It hardly advances the democratic cause to deploy subterfuge and to pass off political commitments as constitutional mandates. Decisions should be celebrated or condemned for the substantive values that they uphold, not for their vague failure to respect some spurious formal distinction between making and applying law.

III.

The Charter crystallized the long-standing dilemma of the courts in trying to reconcile their new role as active guardians of fundamental values with the democratic values and traditions of Canadian society. They had to develop a way to act decisively as well as legitimately. In the Charter's early years, judges relied upon the old standby of "liberal legalism" - a sharp public/private distinction, neutral interpretation, 
and objective balancing - as a method for legitimizing their decisions and reconciling the courts' role with democracy. However, it soon became clear that this jurisprudential modus operandi was failing to placate either liberal or more radical critics who complained that judicial review was not fulfilling its functions as effectively or as democratically as it might. Not only were the courts' efforts at preserving a sharp distinction between legal analysis and political judgment becoming more transparent and unconvincing, but the substantive political values which animated their decisions were being revealed as increasingly outdated and unresponsive to contemporary Canadian sensibilities. Indeed, "liberal legalism" was unable to command a sustained consensus even amongst judges. In response, the Supreme Court began to nurture a less legalistic and more pragmatic approach to its constitutional duties. Ironically, these very efforts to bolster its democratic legitimacy by relying upon an apparently more overt mode of democratic justification revealed even more starkly how undemocratic the judges' involvement in judicial review under the Charter was. ${ }^{10}$

In recent years, there has been a turn to "dialogue theory" as an alternative justification for judicial review. Judges and jurists have begun to accept that a strictly legalistic mode of constitutional adjudication is not available or viable and that some reliance upon contested political commitments is not only inevitable, but also desirable. The primary concern is less with politicization itself and more with "the degree to which judges are free to read their own preferences into law."11 As such, activism is less about whether judges rely on political preferences at all and more about the sources of such values and the extent to which they rely on them. Cautioning that judges are not free to go wherever their personal political preferences take them, the dialogic approach does not abandon the idea or practice of maintaining a barrier between legitimate legal analysis and illegitimate political decision-making. Instead, in contrast to the anti-activists, it is argued that the distinction is much

10 For a full and unimpeachable account of these developments, see A. Petter, Twenty Years of Charter Justification: From Liberal Legalism to Dubious Dialogue (forthcoming, 2004).

K. Roach, The Supreme Court on Trial: Judicial Activism or Democratic Dialogue 106 (Toronto: Irwin Law, 2001). See also Hogg \& Bushell, "The Charter Dialogue Between Courts and Legislatures (Or Perhaps the Charter of Rights Isn't Such a Bad Thing After All)" (1997) 35 Osgoode Hall L.J. 75. 
fuzzier, that the domain of law is much more expansive, and that the boundary between law and politics is much less breached. However, like the anti-activists, they do concede that there is a point at which the judges can be said to be no longer doing law; they will have wandered off into other parts of the constitutional and political domain. In some important sense, law is to exist separately from its judicial spokesperson such that law places some non-trivial constraints on what judges can do and say. While legal principles are more open and sensitive to political context, law is not only reduced to the contingent political preferences of the judiciary.

Consequently, the general thrust of the dialogue theory is that, because the legislature possess the final word on Charter matters by virtue of the section 33 override power, the courts can proceed to engage in a more overt balancing of political values under the section 1 "reasonable limits" provision. The claim and hope is that the courts and the legislature will engage in an institutional conversation about the Charter and its requirements on particular and pressing issues of the day: the courts and the legislators have complementary roles that enable legislation to be carefully tailored to meet the government's political agenda and respect Charter values. The most prominent judicial advocate of a dialogic approach has been Iacobucci J. who insists that "judicial review on Charter grounds brings a certain measure of vitality to the democratic process, in that it fosters both dynamic interaction and accountability amongst the various branches." In establishing a "dialogic balance" and "retaining a forum for dialogue" between the different branches of government, the courts must tread a thin, but vital line between deferential subservience and robust activism. ${ }^{12}$ The courts and legislatures are to be dialogic partners in an institutional conversation to advance shared democratic goals.

While this resort to "democratic dialogue" does at least concede the normative nature of Charter decision-making and represent an effort to get beyond a discredited liberal legalism, it seems to have let the political cat out of the judicial bag without any plan for getting it back in or keeping it suitably leashed. The majority judgments in Doucet again

12 Bell Express Vu Limited Partnership v. R., [2002] 2 S.C.R. 559, [2002] S.C.J. No. 43. See also Vriend v. Alberta, [1998] 1 S.C.R. 493, [1998] S.C.J. No. 29 and Corbiere v. Canada (Minister of Indian and Northern Affairs), [1999] 2 S.C.R. 203, [1999] S.C.J. No. 24. 
offer compelling evidence of this claim. Indeed, suspiciously bereft of any reference to "dialogic theory," the judgment of Iacobucci and Arbour JJ. spends much of its time, directly and indirectly, trying to repel the debilitating spectre of judicial activism. Although the majority emphasizes time and again that "courts must ensure that government behaviour conforms with constitutional norms but in doing so must also be sensitive to the separation of function among the legislative, judicial and executive branches," it is relatively quiet on how that separation is to be achieved. Eschewing the notion that there is some "bright line" in existence, its only serious suggestion is that judges must be thoroughly pragmatic and contextual in their assessments: "determining the boundaries of the courts' proper role, however, cannot be reduced to a simple test or formula; it will vary according to the right at issue and the context of each case." The conclusion that "the judicial approach to remedies must remain flexible and responsive to the needs of a given case" is unlikely to give comfort to those critics who look for some discipline in or direction to the courts' future performance. ${ }^{13}$ Indeed, an uncommitted observer might be forgiven for thinking that, on the question of whether "law is politics," the Court has given up the ghost rather than exorcised the wraith of judicial activism.

Accordingly, with its apparent rejection of judicial objectivity, lack of normative content and vague invocations of democracy, the most recent juristic approaches to judicial review actually serve to undermine fatally the project of justifying Charter adjudication's democratic legitimacy. Although dialogic theory is intended to calm fears that the courts are undisciplined and unlimited in their powers, it manages to reinforce the perception that courts are not only at the centre of the crucial process through which political discourse and values are shaped and sustained, but also that courts get to determine the role and contribution of the other branches of government. The "degree to which judges are free to read their own preferences into law" seems to be reducible to the rather oxymoronic conclusion that they will be as "free to read their own preferences into the law" as "their own preferences" allow. There is a huge gap between the rhetoric of democratic dialogue and the reality of judicial performance. Presenting judicial review as part and parcel of a democratic dialogue merely underlines the extent to which democracy

13 Supra, note 2, at 19, 20 and 25, per Iacobucci and Arbour JJ. 
has become a pathetic caricature of itself. An elite and stilted conversation between the judicial and executive branches of government is an entirely impoverished performance of democracy; it is an empty echo of what should be a more resounding hubbub.

IV.

It is understandable why most judges and jurists wish to ground an objective practice of judicial interpretation that obviates judicial valuechoices and that does not tread on the democratic toes of legislative or executive decision-making. However, it is a misplaced ambition and doomed to failure. As judicial review involves unelected judges invalidating the actions of elected legislators or executives, all judicial review is anti-majoritarian and, therefore, presumptively undemocratic; no theory can reconcile judicial review with majority rule. The Doucet minority are surely correct to emphasize that "the legislature and the executive are ... the principal loci of democratic will." "14 Because there is no way to bring such a project to a satisfactory conclusion, continuing attempts to do so merely exacerbate the problem of democratic legitimacy and erode the very confidence that the legal establishment is trying to maintain. A better response would be to acknowledge that adjudication in a society of diverse and conflicting politics is an inevitably ideological undertaking. Once this is done, courts will not necessarily become otiose or surplus to democratic requirements. Instead, it might be accepted that both courts and legislatures are involved in the same game, namely delivering substantive answers to concrete problems. In doing so, neither courts nor legislatures have a lock on political judgment about what is the best thing to do. Having abandoned the crude Bickelian counter-majoritarian challenge to the courts' democratic legitimacy, ${ }^{15}$ the Supreme Court should follow through on the political logic of its own analysis; it must have the institutional courage of its

14 Supra, note 2, at 41, per LeBel and Deschamps JJ.

15 See A. Bickel, The Least Dangerous Branch: the Supreme Court at the Bar of Politics 2nd ed. (New Haven, Connecticut: Yale University Press, 1986) at 14-18. For a more sophisticated approach, see E. Chemerinsky, Interpreting the Constitution (New York: Praeger Publishers, 1988) at 11-12 and Chemerinsky, "Foreword: The Vanishing Constitution” (1989) 103 Harv. L. Rev. 43. 
own jurisprudential convictions about democracy being more a formal and majoritarian ideal.

Once liberated from the confining strictures of traditional thinking, the question of how and whether courts act with democratic legitimacy is of a very different order and character. The Bickelian difficulty has little to say about what values are important to democracy other than an unthinking regard for majoritarian processes. Once the principle of democracy is accepted to have a substantive as well as formal dimension, the justification for judicial action must also be viewed in substantive as well as formal terms. The work of courts need not be judged by their capacity to be objective and impartial nor by their willingness to be consistent with and not interfere with majority politics. Instead, they can be evaluated in terms of the value choices that they make and the contribution that their decisions make to advancing substantive democracy in the here-and-now. If the traditional presumptions - that legislatures are unprincipled and political and that courts are principled and reasoned - are dropped, it is possible to arrive at a very different understanding and account of the relation between courts and legislatures. For instance, the conclusion is possible that legislatures and courts are both principled and unprincipled to greater and lesser extents at different times and that each can further (as well as inhibit) the cause of democratic justice on a particular issue as much as the other. Moreover, as Doucet suggests, reliance on "principles" is no less political and no more legal in any essential sense. The more pressing conundrum, therefore, is that, if democratic procedures do not guarantee democratic outcomes and democratic outcomes need not result from democratic procedures, how can we best organize constitutional arrangements so that democracy as a whole is more than less likely to prevail?

Accordingly, the appropriate inquiry in a constitutional democracy is not to ask whether the courts have acted politically and, therefore, improperly, but whether the political choices that they have made serve democracy. Because this democratic assessment is substantive and politically undertaking, not formal and analytical, it will always be a contested and contestable issue. Nevertheless, what counts as a democratic decision is not entirely reducible to a political, and, therefore, openended debate about what is most appropriately democratic at the time and under the circumstances. The formal dimension of democracy insists that some account is taken of the general institutional location and position of relative governmental agencies. The fact that legislators are 
elected and judges are unelected has some political salience. However, as Doucet evidences, while judges must respect that distinction, such an allocational decision will itself be political and context-specific. In determining the courts' role in a functioning democracy, there is no authoritative and organizing meta-principle to which the courts can resort that is not itself political and controversial. The scope of the courts' role and power is itself part of the continuing debate about democracy which is a task of the most enduring and political kind. Of course, the concern that courts are interfering too much in the political process is also a valid one. There is a keen need to be vigilant about what courts are (and are not) doing. Any court that tramples too often on the policy-making prerogative of parliament and legislatures is asking for trouble: judges need to recognize that they are part of democracy's supporting cast, not its star performers. But, as the anti-activists fail to acknowledge, that democratic watch should itself be open and honest. It is what the courts are being active about which is the key. It is no more or less political to maintain the status quo than it is to subvert it; conservatism is as ideological as progressivism.

Despite the denials and resistance of traditional judges and jurists, the common law is awash in the roiling and mucky waters of political power. While judges and lawyers claim to keep relatively clean and dry by wearing their institutional wet-suits of abstract neutrality and disinterested fairness, they are up to their necks in ideological muck. And this is no bad thing. Because it is only when judges come clean, as it were, and admit that they have political dirt on their hands that they will appreciate that adjudication generally and constitutional adjudication particularly amount to an organic and messy process that has a similarly organic and messy connection to those social needs which it claims both to reflect and shape. So enlightened, judges might begin to accept that they are involved in a political enterprise whose success and legitimacy are best evaluated not by the courts' formal dexterity and technical competence, but by their substantive contribution to the local advancement of social justice. Abandoning the persistent attachment to a false distinction between a relatively unsoiled practice of principled adjudication and a contaminated involvement in crude politics would be an excellent place to begin such a commitment. As long as its practitioners and their juristic apologists present the constitutional law as an insulated and insular process, courts will run the considerable risk of being unresponsive to and unreflective of the needs they are supposed to address. 
On the other hand, if judges and jurists are more willing to concede that the worlds of law and politics are intimately related, it might become possible to give society's needs the kind of direct and substantive attention that they merit. It is difficult enough for judges to fulfil their daunting roles without them also pretending at the same time that they are engaged in an entirely different enterprise. Efforts at local substantive justice are not enhanced by a mistaken belief that universal or formal coherence is at stake. Legitimacy is best attained by candour and frankness, not by denial and dissemblance.

\section{V.}

What has all this got to do with the present constitutional upheavals in the United Kingdom? In particular, what has this Canadian contretemps got to do with whether the House of Lords should be replaced by a Supreme Court? My answer is "absolutely everything." The most important issues confronting the courts in the United Kingdom today are exactly those which underlie the Doucet decision and which animate public and academic debate in Canada today. This is the problem of "judicial activism" - how can and should the judiciary fulfil its legitimate responsibilities in a way which vigorously enforces contested constitutional dictates as a matter of law against the legislative and/or executive branches of government, but which, at the same time, accepts that it is a body of unelected and unrepresentative bureaucrats which has no direct democratic mandate to make political decisions? Yet the main adversaries in the present constitutional ferment in the United Kingdom seem intent on refusing to acknowledge, let alone deal with that central conundrum. Indeed, while they disagree about much, they join forces in their uncritical acknowledgment that the judicial task has and will continue to be satisfactorily accomplished. If the threat or fear of judicial activism is seen to be a problem at all, it is something for other courts and other jurisdictions to worry about. While the government is at pains to reassure that the need for reform "does not imply any dissatisfaction with the performance of the House of Lords as our highest Court of Law ... [because] its judges have conducted themselves with the utmost integrity and independence ... [and] are widely and rightly admired, nationally and internationally," the judiciary congratulates itself on "the calibre of our existing judiciary, which has resulted in our judiciary 
being admired around the world." ${ }^{\prime 16}$ This is arrogance, complacency and denial on a grand scale.

As in Canada over 20 years ago, the introduction of a Bill of Rights in the United Kingdom has not so much heralded in a new kind of adjudicative performance as highlighted the essentially political dimension of judicial responsibilities. What was once assumed has now become contested. Or, at least, it has been challenged in academic quarters and in the more critical circles of the legal profession. ${ }^{17}$ The sad fact is that the judiciary itself almost wilfully refuses to concede that there might be such an issue, let alone that it might be confronted. The most that the government is prepared to concede is that there might be a perceptual problem in regard to the judicial branch of government: "the considerable growth of judicial review in recent years has inevitably brought the judges more into the political eye.... [and it] is essential that our systems do all that they can to minimise the danger that judges' decisions could be perceived to be politically motivated." ${ }^{\text {"18 }}$ The judiciary is loathe to even make such a concession. Consequently, the present debate is really a faux-debate. Whereas the most crucial challenge to judicial performance is relegated to a vague and distant phantasm of largely foreign concern, the contending forces exhaust themselves (and the peripheral public) in a much less important wrangle over institutional arrangements. While it is clearly a positive contribution to the democratic project not to have the legal system's senior officials being judges, legislators and, in the case of the senior law lord, executives, there will be little genuine progress made in democratic terms unless and until the political dimension of adjudication is acknowledged and addressed. To simply ignore that possibility, let alone its reality, is an insult to democracy and its citizens.

16 See Department of Constitutional Affairs, Constitutional Reform, "A Supreme Court for the United Kingdom" (2003), at 5 and Judges' Council, "Response to the Consultation Papers on Constitutional Reform" (2003), at 26.

17 For a solid survey of the extensive literature and its present "dialogic" turn, see Poole, "Review Article: Dogmatic Liberalism? T R S Allan and The Common Law Constitution" (2002) 65 Mod. L. Rev. 463; and Clayton, "Judicial Deference and 'Democratic Dialogue': The Legitimacy of Judicial Intervention under the Human Rights Act" [2004] Pub. Law 264.

\footnotetext{
18 Supra, note 16, Department of Constitutional Affairs, at 12.
} 
A glance at the decisions by the House of Lords under the Bill of Rights give the lie to the claim that adjudication can proceed without any concerns or qualms about the judges' neutrality and political orientation. Reading decisions like Kebeline and Wallbank might not persuade critics that the judgments were ideological in any overtly bias fashion, but it is difficult to resist the minimal conclusion that political values played an important and integral role in the judges' opinions. ${ }^{19}$ This is not to suggest that the judges acted inappropriately or undemocratically. My charge is much less crude and much more nuanced. As I have been at pains to point out in my discussion of Doucet and its aftermath, it is not that the judges act unprofessionally when they act politically, it is that the professional performance of adjudication cannot be done without resort to contested political values. My account does not in any way report that adjudication is arbitrary or whimsical. Notwithstanding the occasional fall from judicial grace, there is no suggestion that judges do anything other than make a rigorous and responsible fist of their judicial duties. However, this does not refute my claim that law is inevitably and inescapably political in operation and outcome. A realistic understanding of the judicial function leads to the appreciation that adjudication is a subtle combination of freedom (i.e., judges can cobble together the broad range of available doctrinal materials into the artefacts of their choosing) and constraint (i.e., judges are historical creatures whose imagination and craft are bounded by their communal affiliations, interpretive prowess, and personal commitments). ${ }^{20}$ As a profoundly and pervasively political undertaking, adjudication behoves its participants and observers to acknowledge that questions about whether decisions are "politically-motivated" are pertinent and pressing. To ignore flatly and completely such a debate about law and politics is to offend any account and practice of democracy.

19 R. v. DPP, ex p. Kebeline, [2002] 2 A.C. 326, [1999] H.L.J. No. 44 and Parochial Church Council of the Parish of Aston Cantlow v. Wallbank, [2003] 3 All E.R. 1213, [2003] H.L.J. No. 37 on the "freedom" of the courts to adopt a more expansive interpretative role in order to avoid declaration of incompatibility under the Human Rights Act. There is a good discussion of this in Campbell, "Incorporation through Interpretation" in T. Campbell, K. Ewing and A. Tomkins, eds.) Sceptical Essays on Human Rights (2001), at 79.

20 See A. Hutchinson, It's All in the Game: A Non-Foundationalist Account of Law and Adjudication (London: Duke University Press, 2000) and D. Kennedy, A Critique of Adjudication. Fin de Siecle (Cambridge, Mass.: Harvard University Press, 1997). 
For both the government and the judges, the most contentious item of constitutional business is the need to protect and ensure "the independence of the judiciary." This is an important mission. However, the clash between government and judiciary occupies only a small corner of the overall terrain on judicial independence; it is what is not debated and disagreed about that is more significant. Both parties seek to ensure that there is "sufficient transparency of independence from the executive and the legislature to give people the assurance to which they are entitled about the independence of the Judiciary" and that the perception continues that "the Law Lords, like the judiciary as a whole, are independent of the executive and are not susceptible to political pressure from any direction." 21 While it is important that such shields are in place, it is by no means obvious that "judicial independence" is tantamount to the judiciary being left entirely to its own devices and desires. If judicial independence is seen only to be about preserving an almost unaccountable and self-regulated body of constitutional actors, it will not necessarily serve the broader democratic interests of the polity. Indeed, as played out between the government and judiciary, there is no sense in which it might be the politics of the judiciary that is and ought to be in contention. Again, the shared assumption is that, as long as the executive and legislative branches of government keep their noses out, all will be well and non-political because the judiciary can be entrusted to act in a suitably professional and technical manner. As I have insisted, this by no means follows. It is axiomatic that the judiciary be free from government interference whether from the executive or legislative arm of government. However, even if this is secured, it does not mean that all allegations of "politics" have been resolved. There is much more to politics than whether the judiciary is making decisions which are favourable to the government of the day. For example, decisions which go against the government are not by that fact free from politics. Presumably, decisions which go against the government can be as equally politically-motivated as those that do not go against the government. Judicial

21 Supra, note 16, Department of Constitutional Affairs, at 12, and Judges' Council, at 48. 
independence, therefore, is about much more than institutional independence: it is also about political leanings. ${ }^{22}$

VI.

The true colours of the judiciary and, to a lesser extent, the government (which, of course, is itself staffed by lawyers on these matters) are revealed in the details of proposed changes to the judicial appointments process. After all, the "who" of adjudication is as or more important than the "what." As regards the new Supreme Court, the government's preference is for a 15-member Commission (comprising five judges, five lawyers, and five non-lawyers) to recommend a limited number of names to the Prime Minister who would then make the appointment. Again, the concern is primarily perceptual: "whether or not the system really is biased, the perception has an impact which is real enough." However, the government concedes that the appointments must be based on "merit" because "the public must have confidence that judges are independent, impartial and of complete integrity, as well as possessing the intellectual skills and personal qualities of the highest calibre which are required for the discharge of their duties." Not surprisingly, the judiciary resoundingly echo these sentiments. While "increasing the diversity of our judiciary ... will help to generate public confidence in the justice system," the judiciary maintain that it is imperative that "best qualified candidate is appointed irrespective of his or her background" and that the Commission avoid " becoming so anxious to achieve diversity that sight is lost of the primacy of merit." ${ }^{, 3}$ Nevertheless, notwithstanding these reservations, Lord Falconer, the Lord Chancellor, recently told the Commons' Constitutional Affairs Committee that the new appointments body must select women and ethnic minority judges. While it would be up to the Commission to decide on the actual criteria, Falconer did hint at the fact that "targets" might need to be set to ensure that a representative diversity is achieved. ${ }^{24}$

22 See J.A.G. Griffiths, The Politics of the Judiciary, 5th ed. (London: Fontana Press, 1997).

Department of Constitutional Affairs, Constitutional Reform: A New Way of Appointing Judges (2003), at 20, and supra, note 16, Judges' Council, at 4, 28 and 31.

${ }^{24}$ Press Association News, "No Further Delay on Judicial System Reforms" (6 January 2004). 
As viewed by both sides, there is a shared assumption that "merit" and "diversity" are somehow independent and unrelated categories: an increase in diversity will threaten to undermine merit and a reliance on merit will preclude diversity. This is entirely wrong-headed. First of all, "merit" is an entirely relative notion. Whether a person has the necessary capacities and talents to be successful at a given role or activity will depend upon an evaluation of the nature of that role. As I hope will now be obvious, what qualities and characteristics best comprise the "good judge" will itself be a political and contestable debate. If, as the British judiciary seem to maintain, the holding of judicial office is purely about the intellectual and formal attributes of professional judgment, then there is little point in bothering too much about diversity. However, if that were the case, there is no reason to expect that the judiciary would be a starkly undiverse body as it presently is. Indeed, one could be forgiven for thinking that greater diversity would indeed be an improvement in merit because, with no visible minorities on any superior court and with the first women appointed to the House of Lords only very recently, there has been a consistent willingness to translate "background" into "best qualified." But if, as I have argued, adjudication involves an inescapable political element, it will be important to ensure that the judiciary represent a broader cross-section of society than it presently does. This is not to argue that diversity and merit are one and the same thing or that diversity will always be preferable to merit. On the contrary, it is to argue that diversity and merit are interconnected. While there is a need for meritorious candidates, it is nonsensical to believe that only white males possess the necessary meritorious qualities; this is the very essence of racism.

Recognizing that adjudication requires and expects judges to make choices among competing political values and that there is no neutral way to make those choices, it will be wise to work towards a process of appointment which embraces this operating assumption rather than one which goes to enormous lengths to hide and reject it. By appointing more women and visible minorities to the courts, the merit of the bench will be enhanced in that citizens might be reassured that more than one set of political values and experiences will be in play when judicial decisions are made. In making this plea for increased diversity, I am not claiming that identity is a reliable proxy for set values: people of similar backgrounds and identities do not possess the same politics merely by virtue of that fact. However, as a pragmatic consideration rather than an 
ontological assertion, it can be safely suggested that background and identity matter. It is a conceit of established groups (white, male, heterosexual, etc.) to maintain that professional objectivity is the only valid touchstone of legal knowledge. Too often that objectivity has turned out to be little more than those groups' own partial and establishment interests in intellectual garb. If British society were rid of discrimination and had achieved a genuine state of equality, the appointment of women (visible minorities, gays, etc.) to elite institutions (white, male, etc.), like the proposed Supreme Court, might not be so urgent or desirable. However, the fact is, of course, that society is still very much marked by discrimination and inequality. Accordingly, to be a woman (visible minority, gay, etc.) is still to be the object of persecution because of, and not in spite of, one's identity. Unfortunately, the courts are no less culpable than any other institutions in this history. Consequently, the experience of being a woman (visible minority, gay, etc.) remains critical to a full understanding of what it is to be a woman (visible minority, gay, etc.) and why women (visible minority, gay, etc.) judges are required in today's society. ${ }^{25}$

Judicial independence must also be balanced against judicial accountability. One of the better ways to achieve that is by way of diverse appointments through a democratic process. Indeed, the proposal to have the appointing Commission dominated by lawyers and judges in terms of numerical supremacy and controlling influence is simply unacceptable. There is an inevitable politics to judicial appointments; there always has been and always will be, even if it masquerades under the dubious label of "merit." The choice is not between a political and a non-political process of judicial appointments. Rather, it is a straightforward choice about whether the politics of the judiciary or the politics of the public at large, as expressed by its elected representatives, should prevail. While many will consider this a weak or even dangerous

25 As appointments to the Supreme Court of Canada show, the performance of its women judges has been varied and far from uniform in political commitments. See, for example, R. v. Morgentaler, [1988] 1 S.C.R. 30, at 161-84, per Wilson J., [1988] S.C.J. No. 1; R. v. Lavallee, [1990] 1 S.C.R. 852, at 856-97, per Wilson J., [1990] S.C.J. No. 36; Symes v. Canada, [1993] 4 S.C.R. 695, at 776-832, per L'Heureux-Dubé J., [1993] S.C.J. No. 131; R. v. Seaboyer, [1991] 2 S.C.R. 577, at 597-642, per MacLachlin J., and at 643-713, per L'Heureux-Dubé J., [1991] S.C.J. No. 62; and R. v. Carosella, [1997] 1 S.C.R. 8, at 114-55, per L'Heureux-Dubé J., [1997] S.C.J. No. 12. 
reform, it is necessitated by the nature and performance of the judicial function in a 21 st Century constitutional democracy. Such a politicallyinformed and politically-charged process will not contribute to a greater politicization of the judiciary because judges are already and inevitably a throughly political group. It will instead bring those politics into public view and render them more available for public scrutiny: the politics of the public has more democratic legitimacy than that of the judges. Hence, the need to ensure judicial independence is not resolved by abandoning all efforts at accountability. There needs to be a democratic trade-off between independence and accountability. If judicial independence is to mean that judges are left almost unregulated in their activities and behaviour, it is vital that the process by which they are appointed be as democratic as possible. This most certainly does not mean that the legislative branches have no role to play as the present debate seems to suggest. Indeed, it is only with the involvement of these branches of government that the courts can be entrusted to fulfil their adjudicative responsibilities in a meaningful, if strained democratic manner.

Mindful of the adage that "politics is the art of the possible," it is worthwhile offering some alternative proposals to the tepid proposals for reform put forward by the government. While there are more radical measures which might be taken, there are several less extreme steps that could be adopted which would better incorporate the understanding that law is politics and that judicial decision-making requires judges to make contested and controversial political choices. ${ }^{26}$ The most important innovation would be to create a more democratic appointments process. This could be achieved by establishing an independent commission. Any such body would need to be as diverse and as representative as possible. Accordingly, it might consist of about 15 members of whom

26 Of course, there is no compelling reason why courts should remain at the centre of constitutional politics. For instance, Mark Tushnet has been developing a rich and provocative body of work on how best to develop non-judicial forums for constitutional decisionmaking. See, e.g., Taking the Constitution away from the Courts (Princeton: Princeton University Press, 1999) and "Non-Judicial Review" (2003) 40 Harv. J. on Legis. 453. In cobbling together my own alternatives, I have benefited immensely from the ideas of Legg, Woodhouse, Himsworth and Patterson, and Le Sueur, in this volume, and Ewing, "A Theory of Democratic Adjudication: Towards a Representative, Accountable and Independent Judiciary" (2000) 38 Alta L. Rev. 208. 
five would be appointed from the House of Commons, five would be judges, and five would be citizens; tenure on the committee would be limited to three years and the chair of the commission would be one of the lay members. Confident that no particular constituency (i.e., judicial, political or lay) had a lock on the commission's work or decisions, the commission's task would be to establish appropriate criteria for appointment which took seriously the need for a diverse and talented judiciary. Candidates could be identified either by application, nomination or search: interviews would be held and candidates would be subject to an intensive vetting. There could be rules to ensure both geographical representation (i.e., two supreme court judges for Scotland and one for Northern Ireland) and diversity in terms of women and visible minorities. Also, threshold rules for eligibility in regard to professional experience and qualification might be relaxed to ensure that otherwise meritorious candidates were not excluded. Contrary to the government's view that "it is at lower levels of the Judiciary that the criteria might need to be re-examined," ${ }^{27}$ such innovations are best made at the highest level in order to confirm the sincerity and importance of the commitment to diversity and change. In all its activities, the commission would ensure that diversity was not a secondary consideration, but a primary component of "merit."

The recommendations of the commission would be final and direct. The diverse composition and democratic operation of the commission would obviate the need for approval by the Prime Minister or confirmation hearings in Parliament. This is not because such procedures are "inconsistent with the move to take the Supreme Court out of the potential political arena," but because the commission itself will perform such a role more effectively and will be less likely to turn the appointments process into a media circus as in the United States. Furthermore, there should be a complement of nine supreme court judges who, except on leave applications and conflicts, should always sit as a full court: this would not only reduce the opportunities for inconsistent decisions, but would also avoid any suggestions of manipulation in panel-selection. It cannot simply be concluded that, whereas "in the United States, appointments to the Supreme Court are more political, and therefore there is a stronger possibility that the composition of the court might affect

27 Supra, note 16, Department of Constitutional Affairs, at 33. 
the outcome, ... this is not the case in the United Kingdom." 28 Also, there should be a public register of "judicial interests" and a tougher set of conflicts rules under a comprehensive Code of Judicial Conduct which could be administered by the appointments commission. Judges should also have a fixed tenure of appointment of no more than 12 years. While the commission would have the power to receive complaints and discipline judges, it would not be able to dismiss judges without formal approval by parliament. Finally, to put the performance of the Supreme Court judges on a more secure and less amateurish footing, there should be a better administrative infrastructure and support staff: better communication on the Court's activities could be developed and executive "headnotes" of decisions might be provided. While this package of reform proposals will not guarantee both the democratic accountability and institutional independence of the judiciary, it will better deal with the realities of judicial authority and power in a constitutional democracy.

\section{VII.}

Much of the immediate Canadian response to Doucet has been framed by the concern over whether the judiciary had trespassed on forbidden political ground. However, there seems a broader and more troubling dynamic underlying the litigated issue - that democratic choice should not be only between rule by a judicial elite or a governmental elite, but through a political process that is more responsive to broader constitutional and democratic concerns. To conceive that the Doucet decision resurrects only the dilemma of whether courts can or should invade the political domain misses the main point: courts cannot exercise their powers and responsibilities without reference to contested values and principles of governance. The real and neglected issue is not the politicization of the judiciary, but the democratic failure of the executive and legislative in fulfilling their constitutional responsibilities and mandate. If governments and legislatures were truly representative and were doing more of what they were supposed to being doing in a constitutional democracy, the question of what judges do would be less

$28 I d$, at 34 and 38 . 
pressing and more incidental. If there is a crisis in Canadian democracy, it is to be found in the fact that politicians and legislators are simply not "democrats" in the full sense of the term. "Democracy" is used more as a rhetorical cloak for elitist practice than a measure and guide for popular politics. After all, a drop in voter turnout in federal elections from 76 per cent in 1979 to 61 per cent in 2000 is hardly reassuring.

Ironically, the Canadian Charter of Rights and Freedoms is viewed favourably and increasingly so by large majorities in all regions, with the highest rate of approval of 91 per cent in Quebec, and the lowest of 86 per cent in the West. Moreover, 71 per cent say that the Court and not parliament should have the final say when the Supreme Court declares a law unconstitutional because it conflicts with the Charter. Indeed, 66 per cent say they trust judges to do the right thing either all the time or most of the time. Furthermore, "the Charter is seen as important to Canadian identity by more people than is the national anthem or the flag." ${ }^{29}$ Nevertheless, the fact that public opinion polls show considerable support for the Supreme Court is less an accolade for judges and more a slap in the face for politicians, particularly those leaders who preside in and over cabinet. Judges can only ever do a second-best job at making up the democratic deficit in the present performance of Canadian politics. The Supreme Court decision in Doucet is indicative of that. While the judiciary has some defined and important function in Canadian politics, it must be limited and partial. Being neither elected by nor representative of Canadians, judges can never be entirely or rightly sanguine about the force and solidity of their democratic legitimacy. On the other hand, while the executive can lay claim to greater democratic legitimacy, its practical exercise of power offends its democratic pedigree. Too often, political leaders seem to dance to their own tune rather than that of the people they represent. Increased "rule by cabinet" is hardly that much better than extended "rule by the Supreme Court." While the statistics reveal interesting support for the courts, they express profound dissatisfaction with the political leaders: only 22 per cent of Canadians trust their leaders to do the right thing at all.

To revamp the legislative and executive process in line with greater popular participation and political accountability will require a

29 Centre for Research and Information on Canada, The Charter: Dividing or Uniting Canadians? (2003), at 6. 
monumental effort. Any changes - proportional representation, recall legislation, accountability audits, genuine ministerial responsibility, referenda, etc. - must themselves be products of the very democratic process that is to be enhanced. There are no easy solutions to the present un-democratic trends. However, the debate around judicial activism is something of a distraction. Improvement in Canada's democratic status will not come from increased interventions by judges in the micromanagement of governmental policies. Indeed, judicial supervision is a short-term crutch that actually harms a limping polity in the mediumand long-term. The replacement of one elite rule (executive) by another (judicial) can only be considered positive under the most warped sense of democracy. So, if there is a desire to rein in the judges, there must also be a commitment to ensuring that elected politicians and officials are living up to their own and demanding constitutional and democratic responsibilities. At present, they are palpably not. But simply construing the democratic challenge as being one about whether the judges stay out of or stray onto the political terrain is to misrepresent the problem and, therefore, to hamper any genuine solutions.

Despite the regular rounds of self-congratulation about Canada's ranking as one of the best societies to live in, there is a serious erosion of basic democratic precepts. ${ }^{30}$ The twin foundations of democracy popular participation and political accountability - are going the way of the polar ice-caps. There seems to be an implicit Faustian bargain between elite and rank-and-file that the price of socio-economic advancement (which is still questionable when looked at in other than mean or median terms) is at the cost of democratic involvement. The Charter and its judicial enforcement are part of that arrangement. Whatever else it means, democracy demands that there be more power to the people and less to the elites. Aristocratic rule is no less palatable because judges and political leaders are the new dukes and barons. And, it is certainly no more acceptable when such elites wrap themselves in the trappings of democracy. While there has never been a golden age for Canadian democracy, what now passes for "democracy" is an exclusive, sporadic and sketchy conversation between the judicial and executive branches of government over what is best for the country. In this

30 See, for example, Human Development Report, Deepening Democracy in a Fragmented World (2002). 
exchange, the voices of ordinary Canadians play no real or substantive role. Of course, a robust judiciary has a definite role in a vital democracy, but judges can only ever do a second-best job at making up the democratic deficit in the present performance of Canadian politics; they are neither positioned nor skilled to handle such a task. Nevertheless, it is a sign of a healthy democracy that Canadians are at least arguing about and grappling with "judicial activism" and its implications for a constitutional polity. If the present debate about establishing a new Supreme Court is anything to go by, the British are still in denial and have not even begun to take the problems seriously - "ignorant armies," "confused alarms," and "a darkling plain" indeed. 
